\title{
The Importance of a Simulation Laboratory in the Development of a Medical Faculty
}

\section{Bir Tıp Fakültesinin Gelişiminde Simülasyon Laboratuvarının Önemi}

\author{
Ayhan Özhasenekler ${ }^{1}$, Reyhan Ersoy ${ }^{2}$ \\ ${ }^{1}$ Ankara Yıldırım Beyazıt University Medical Faculty, Department of Emergency Medicine, Coordinator \\ of Clinical Skills Education Committee, Deputy Dean \\ ${ }^{2}$ Ankara Yıldırım Beyazıt University Medical Faculty, Dean
}

\section{Correspondence / Yazışma Adresi}

Dr. Ayhan Özhasenekler

Ankara Yıldırım Beyazıt University Medical Faculty, Deputy Dean, Bilkent / Ankara

e-mail: drhasenek@hotmail.com

Date of submission: 16.04 .2018

Date of admission: 24.05. 2018

\section{Dear Editor,}

The use of new educational tools has been increased due to technological developments. ${ }^{1}$ These developments have enabled the proliferation of simulation applications, which are used commonly for increasing skills in medical personnel education as being a dependable educational method. ${ }^{2}$ Thus, it is necessary to establish laboratory environments which enable students' active participation in the learning process and where technical equipments and installation are found by which the students can practice patient care and these also enable simulation education to be given. ${ }^{3,4}$

For this purpose, a simulation laboratory has been established at Ankara Yildirim Beyazit University Medical Faculty Deaconship and Lecture Halls building in March 2017. Our laboratory has simple and medium level models and advanced level simulation models. It consists of 5 rooms of around $10 \mathrm{~m}^{2}$ prepared in policlinic conditions, also a debriefing saloon, an inpatient service, a control centre, a store and a secretariat. Since the rooms, the inpatient service and the debriefing saloon have a camera, loudspeaker and microphone background, they are suitable for making structured clinical exams (Picture 1). In this section, basic and advanced life support, airway and injection application, naso-gastric and foley catheter application, blood pressure measurement, the establishment of peripheral and central vascular access, intraosseous application, suturing, rectal and prostate examinations, breast and vaginal examinations and birth models are all available.

Also, in the inpatient service there is a bed-side monitor with high technological equipment which enables auscultating heart, lung and intestinal sounds and fetal heart sounds and which shows cardiac rhythm, saturation, respiratory rate and pulse rate. There are four precision models with handheld computers planned to be used by the instructor and any scenario can be planned upon about the mentioned parameters. Our Simulation Laboratory is used actively by the Clinics of Emergency Medicine, 
Internal Diseases, Cardiology, Chest Diseases, Anesthesiology and Reanimation, General Surgery and Obstetrics as a part of internship programs of Term IV and Term $\mathrm{V}$. It is also used in the specialty education programs after graduation.

It is important to have a simulation laboratory for a medical faculty both within the scope of The Council of Higher Education quality standards and in terms of accreditation. It is a truth that the applications made in the simulation laboratory accelerate learning process, establish a safe environment for the students, decrease anxiety which may arise during actual practice, contribute skills, decision, evaluation, team work and communication skills.
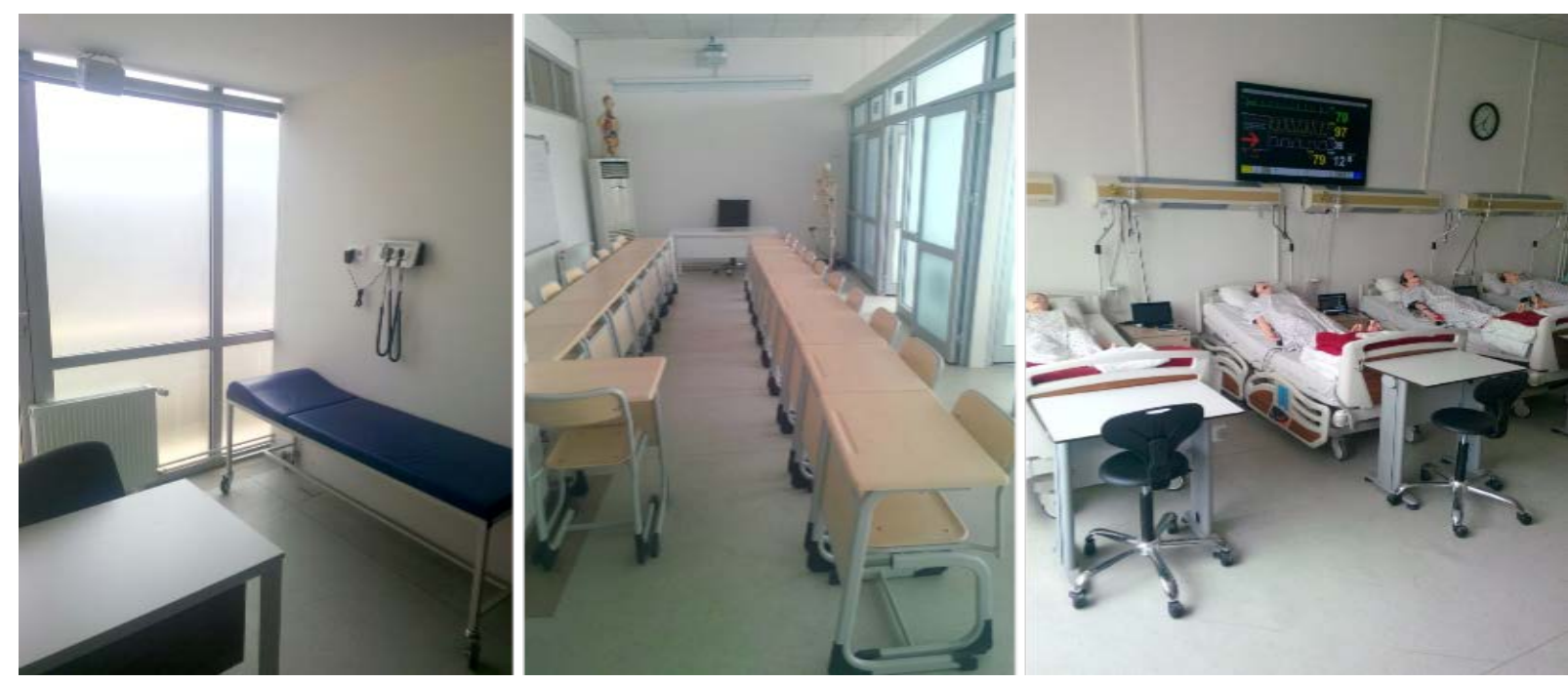

Picture 1. Policlinic room, debriefing saloon and inpatient service in the simulation laboratory.

\section{References}

1. Mıdık Ö, Kartal M. Simulasyona dayalı tıp eğitimi. Marmara Medical Journal 2010;23(3):389-99.

2. Miller A, Bull RM. Do you want to play? Factors influencing nurse academics' adoption of simulation in their teaching practices. Nurse Education Today 2013;33:241-6.

3. Göriş S, Bilgi N, Korkut Bayındır S. Hemşirelik eğitiminde simülasyon kullanımı. Düzce Üniversitesi Sağllk Bilimleri Enstitüsü Dergisi 2014;4(2):25-9.

4. Thoureen TL, Scott SB. Use of simulation in emergency department. In: Practical Teaching in Emergency Medicine, Rogers RL. Mattu A. Winters ME. Martinez JP. Mulligan TM (eds). 2nd ed. Chichester, West Sussex : John Wiley \& Sons; 2013:177-86. 